\title{
METODE AMINA WADUD DALAM PENAFSIRAN A1-QURAN
}

\author{
Ahmad Zabidi \\ Institut Agama Islam Sultan Muhammad Syafiuddin Sambas \\ Corresponding Author e-mail: ahmadsbs462@gmail.com
}

\begin{abstract}
Amina Wadud, in the introduction to one of her books, "The Qur'an According to Women: Re-reading the Holy Scriptures with the Spirit of Justice", states that it is not the text of the Koran that limits women, but the interpretation of religious texts which limits them which are considered more important than the Koran itself. Amina also revealed that the importance of analyzing the concept of the Koran about women must be measured from the perspective of the Koran itself, both as a strength in history, politics, language, culture, scholarship, and spirituality, as well as a holy book. The study of Amina Wadud Muhsin's method in understanding the verses of the Koran seeks to reinterpret various verses of the Koran that have tended to be interpreted patriarchically by classical commentators, so the method used in interpreting the Koran uses holistic approach.
\end{abstract}

Keywords: Method, al-Qur'an, interpretation

\begin{abstract}
ABSTRAK
Amina Wadud dalam pengantar salah satu bukunya, "Qur'an Menurut Perempuan: Membaca Kembali Kitab Suci dengan Semangat Keadilan", menyatakan bahwa bukan tentang teks al-Qur'an yang membatasi perempuan, melainkan penafsiran terhadap teks teks keagamaan itulah yang membatasinya yang dianggap lebih penting dari pada al-Qur'an sendiri. Amina juga mengungkapkan bahwa arti penting analisis tentang konsep al-Qur'an tentang perempuan, harus diukur dari perspektif alQur'an sendiri, baik sebagai kekuatan dalam sejarah, politik, bahasa, budaya, kecendekiawanan, dan spiritualitas, maupun sebagai kitab suci. Kajian tentang metode Amina Wadud Muhsin dalam memahami ayat-ayat al-Qur'an berupaya menafsirkan ulang berbagai ayat al-Qur'an yang selama ini cenderung ditafsirkan secara patriarkhis oleh para mufasir klasik, maka metode yang digunakan dalam penafsiran al-Qur'an menggunakan pendekatan holistik.
\end{abstract}

Kata Kunci: Metode, al-Qur'an, penafsiran

\section{PENDAHULUAN}

Al-Qur'an mempunyai posisi penting dalam studi-studi keislaman, di samping berfungsi sebagai petunjuk, al-Qur'an juga berfungsi sebagai Furqan (pembeda) yaitu menjadi tolak ukur dan pembeda antara yang haq dan yang bathil. Menafsirkan al-Qur'an berarti berusaha menerangkan makna-makna al-Qur'an dan mengeluarkan hukum-hukumnya dan hikmah-hikmahnya. Oleh karena pentingnya posisi al-Qur'an tersebut, 
maka penafsiran terhadap al-Qur'an bukan hanya merupakan hal yang diperbolehkan, bahkan lebih dari itu, merupakan suatu keharusan bagi orang-orang yang memenuhi kualifikasi untuk melakukannya. Kecenderungan hermeneutika dalam model penafsiran feminis telah memunculkan hasil penafsiran yang berbeda secara diametral dengan penafsiran klasik.

Dalam konteks keagamaan mulai beredar isu pentingnya terhadap reinterpretasi ayat-ayat gender, untuk menemukan atribut-atribut sosial yang selama ini masuk dalam penafsiran al-Qur'an, menelaah kembali semangat keadilan dan kemanusiaan yang dibawa oleh Islam. Kemajuan ini, di satu sisi memberikan perubahan terhadap paradigma berpikir, telah menyita perhatian intelektual muslim-feminis untuk melakukan pengembangan metodologis, guna melahirkan penafsiran yang berperspektif gender dan berkeadilan sosial, diantaranya adalah apa yang akan digagas oleh Amina Wadud Muhsin.

Pendekatan gender terhadap dehumanisasi sosial mulai dilakukan para aktivis, seiring dengan maraknya isu kesetaraan dan kemitrasejajaran antara perempuan dan laki-laki. Pendekatan gender melahirkan kesadaran sosial bahwa selama dalam realitas sosial telah terjadi diskrimasi dan penganiayaan yang secara langsung atau tidak langsung dirasakan terhadap dan oleh kaum perempuan itu sendiri. Di antara hal baru yang giat dilakukan yaitu melakukan analisis atas beberapa atribut sosial dan keagamaan yang selama ini menjadi justifikasi ketidak adilan sosial.

\section{METODE PENELITIAN}

Penelitian ini menggunakan metode penelitian analisis isi (contentanalisys). Analisis isi adalah suatu teknik penelitian untuk membuat kesimpulan-kesimpulan yang dapat ditiru dan sahih data dengan memperhatikan konteksnya. Sebagai suatu teknik penelitian, analisis isi mencakup prosedur-prosedur khusus untuk pemrosesan data ilmiah dengan menggunakan pendekatan library research (pustaka).

\section{PEMBAHASAN}

1. Pemikiran Amina Wadud dalam penafsiran al-Qur'an a. Amina Wadud dan karyanya

Amina Wadud Muhsin disebut dengan Amina Wadud lahir di Negara Amerika Serikat pada tahun 1952, menurut Khudori Soleh (2003: 66), Amina merupakan warga Amerika Serikat keturunan Afrika-Amerika (kulit hitam). Amina menjadi seorang muslimah kirakira pada akhir tahun 1970-an, namun berkat ketekunan dalam melakukan studi keislaman menjadi seorang pemikir yang bisa diandalkan dedikasi keilmuannya terhadap Islam. Amina juga pernah selama tiga tahun memberi kuliah pada Universitas Islam Internasional, di Kuala Lumpur Malaysia. Sebelumnya, menyelesaikan studi di Universitas Michigan dan mendapat gelar MA pada tahun 1982 dan gelar $\mathrm{Ph}$. D pada tahun 1988. Selain bahasa Inggris, Amina juga menguasai beberapa bahasa lain seperti; Arab, Turki, Spanyol, dan Jerman (Marwan Saridjo, 2005). 
Amina termasuk tokoh feminis muslim yang cukup produktif baik berupa buku, artikel yang dimuat dalam beberapa jurnal, seminar-seminar, dan beberapa proposal Research (proposal penelitian) dalam bidang perempuan, gender, agama, pluralisme dan kemanusiaan. Karya-karyanya tersebut antara lain dalam bentuk buku dan artikel diantaranya:

1) Qur'an and Women: Rereading the Sacred Textform a Women's perspective (Oxford University Press: 1999).

2) Qur'an and Women (Fajar Bakti Publication, Oxford University Press Subsidiary), Kuala Lumpur Malaysia (Original Eddition, 1992).

3) Alternatif Penafsiran Terhadap Al-Qur'an dan Strategi KekuasaanWanita Muslim, dalam buku "Tirai Kekuasaan: Aktivitas KeilmuanWanita Muslim", Editorial Gisela Webb, Syracuse University Press, 1999.

4) Gender, Budaya dan Agama: Sebuah Perspektif Islam, dalam buku "Gender, Budaya dan Agama: Kesederajatan di Hadapan Tuhan dan Ketidak sederajatan di Hadapan Laki-laki", Editorial Norani Othman dan Cecilia Ng, Persatuan Sains Sosial, Kuala lumpur Malaysia, 1995.

5) Mencari Suara Wanita dalam al-Qur'an, dalam Orbis Book, SCM Press, 1998.

6) Muslim Amerika: Etnis Bangsa dan Kemajuan Islam, dalam buku"Kemajuan Islam; Keadilan, Gender dan Pluralisme" Editorial Omid Safi, Oxford: One World Publication, 2002.

7) Parameter Pengertian al-Qur'an terhadap Peran Perempuan dalam Konteks dunia Modern, dalam Jurnal "Islamic Quarterly", edisi Juli, 1992 .

8) Qur'an, Gender dan Kemungkinan Penafsiran, dalam Jurnal "Kesepahaman Muslim-Kristen", Georgetown University, Washington DC.

9) Qur'an, Syari'ah dan Hak Politik Wanita Muslim, makalah Simposium" Hukum Syari'ah dan Negara Modern", Kuala Lumpur Malaysia, 1994.

10) Wanita Muslim: Antara Kewarganegaraan dan Keyakinan, dalam Jurnal "Women andCitizenship".

11) Wanita Muslim sebagai Minoritas, dalam "Journal of Muslim MinorityAffairs", London, 1998.

12) Ayat 4:34: Sebuah Konsep Kedinamisan Hubungan antara Perempuan dan Laki-laki dalam Islam, dalam "Malaysian Law News", Edisi Juli, 1990.

b. Pemikiran Amina Wadud

Latar belakang dari pemikiran Amina Wadud mengeluarkan metode tafsir berawal dari asumsinya bahwa menurutnya tidak adanya metode dan kategori tafsir yang benar-benar objektif dalam melakukan penafsiran terhadap al-Qur'an. Pada dasarnya pemikiran Amina Wadud dalam menafsirkan al-Qur'an banyak dipengaruhi oleh 
pemikiran "Neo-Modernisme" Fazlur Rahman, terutama dengan corak penafsiran al-Qur'an yang digunakan oleh Amina Wadud (metode penafsiran holistic) yang menekankan telaah aspek normative dari ajaran al-Qur'an.

Metode adalah cara yang teratur dan terpikir baik-baik untuk mencapai maksud (Departemen Pendidikan dan Kebudayaan, 1989: 580-581). Mengenai metode tafsir holistik, baik Amina Wadud maupun Fazlur Rahman (salah satu pengguna metode penafsiran holistik) tidak memberikan definisi secara eksplisit, namun secara umum ini merupakan metode hermeneutika dalam menafsirkan alQur'an (Hassan Shadili, tth: 2230). Menurut M Amin Summa (2001: 109) Dengan cara ini Amina Wadud menitik beratkan pemahaman pada susunan bahasa al-Qur'an yang bermakna ganda. Tujuan dari metode ini adalah untuk menggambarkan maksud teks disertai "prior teks" (persepsi, keadaan, latar belakang) orang yang menginterpretasikan al-Qur'an.

Tafsir bentuk masdar dari kata kerja fassara yang secara etimologi berarti al-ibanat (penjelasan) dan kasyf al-mughaththa (menyingkap yang tertutup). (Mazd al-Dîn Muhammad Ibn Ya'kūb alFairuzabadi, 1995: 411). Al-Jurjani berpendapat bahwa kata tafsir menurut pengertian bahasa adalah al-Kasyf wa al-Izhar yang artinya menyingkap dan melahirkan. Menurut Al-Dzahabi (1976: 15) lebih lanjut menjelaskan bahwa tafsir itu adalah ilmu yang meneliti maksud firman Allâh SWT dalam batas-batas kemampuan manusia. Ditinjau dari sudut aksiologi mencerminkan kepentingan teoritis memperjelas makna dan pemahaman teks al-Quran yang diadaptasikan dengan situasi historis penafsir. Sedangkan menurut pendapat yang lain, tafsir merupakan usaha untuk memperjelas makna teks al-Qur'an, termasuk usaha untuk mengadaptasikan teks al-Qur'an kedalam situasi kontemporer seorang mufasir (Ihsan Ali Fauzi, Jurnal 'Ulum Al-Qurân, no 5, Vol II, 1990/1410:13).

Holistic adalah cara pandang terhadap sesuatu yang dilakukan dengan konsep pengakuan bahwa hal keseluruhan adalah sebuah kesatuan yang lebih penting dari pada bagian-bagian yang membentuknya. Dengan demikian dapat dipahami bahwa metode tafsir holistik adalah cara memahami al-Qur'an dengan satu kesatuan.

Amina Wadud menggunakan prinsip umum al-Qur'an dalam rangka mengkontekstualisasikan al-Qur'an dengan problem yang dihadapi (contoh problem gender) dengan cara memahami al-Qur'an dengan satu kesatuan. Urgensi memahami al-Qur'an dengan satu kesatuan, dikarenakan al-Qur'an bukanlah kumpulan tulisan memiliki hubungan antar bab dan sub bab yang jelas. Sebaliknya alQur'an diwahyukan dengan tuntunan situasi dan kondisi yang dihadapinya.

Amina berharap dengan metode holistic akan diperoleh interpretasi al-Qur'an yang mempunyai makna dan kandungan selaras dengan konteks kehidupan modern. Amina Wadud 
menandaskan bahwa kandungan dan prinsip umum yang menjadi dasar al-Qur'an tetap bersifat abadi, karena prinsip tersebut tidak terbatas pada situasi historis saat al-Qur'an diwahyukan.

Berikut contoh pernafsiran Amina Wadud tentang asal usul manusia dan kesetaraan gender. Bahasan mengenai asal usul manusia dan kesetaraan gender, Amina Wadud merujuk pada firman Allah swt. dalam Q.S al-Nisā' [4]: 1.

Terjemahnya:

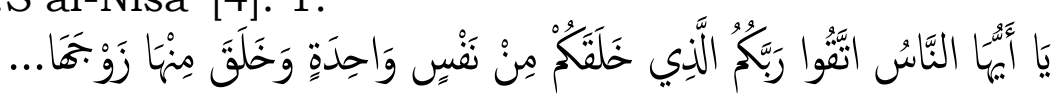

Wahai sekalian manusia, bertakwalah kepada Tuhan-mu yang telah menciptakan kamu dari diri yang satu, dan daripadanya Allah menciptakan istrinya (Kementerian Agama RI, Q.S al-Nisā' [4]: 1.).

Dalam Q.S al-Rum [30]: 21.

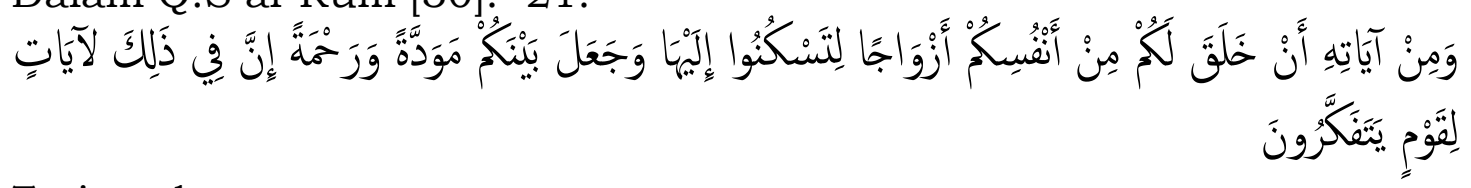

Terjemahnya:

Dan di antara tanda-tanda kekuasaan-Nya ialah Dia menciptakan untukmu istri-istri dari jenismu sendiri, supaya kamu cenderung dan merasa tenteram kepadanya, dan dijadikan-Nya di antaramu rasa kasih dan sayang. Sesungguhnya pada yang demikian itu benarbenar terdapat tanda-tanda bagi kaum yang berpikir (Kementerian Agama RI, Q.S al-Rum [30]: 21).

Menurut Amina Wadud (2001: 57-58) yang perlu dikritik ulang adalah kata nafs wahidah dan zauj. Menurutya kedua ayat tersebut menjelaskan tentang kisah asal usul manusia versi al-Qur'an, tanpa kejelasan tentang Adam dan Hawa. Namun ayat tersebut dipahami sebagai penciptaan Adam dan Hawa. Dari akar katanya nafs adalah muannas, akan tetapi kenapa ditafsirkan sebagai lelaki (Adam). Menurut Amina Wadud, nafs menunjukan bahwa seluruh manusia itu berasal dari asal yang sama. Kata zauj sendiri sifatnya netral karena secara konseptual kebahasaan juga tidak menunjukkan bentuk muannas atau muzakkar. Kata zauj yang bentuk jamaknya azwaj ini sering digunakan untuk menyebut tanaman (QS. alRahman [55]: 52) dan hewan (QS. Hud [11] :40). Mengapa para mufassir tradisional menafsirkan zauj dengan makna istri, yakni Hawa? Amina Wadud tidak sependapat dengan penafsiran tersebut.

c. Kritik Amina Wadud terhadap Metode dan Kategori Tafsir

Amina mengasumsikan dasar kerangka pemikirannya adalah bahwa al-Qur'an tetap merupakan sumber tertinggi yang secara adil mendudukkan laki-laki dan perempuan setara. Karena itu, perintah dan petunjuk Islam yang termuat dalam al-Qur'an semestinya diinterpretasikan dalam konteks historis qur'an yang spesifik. 
Mengenai penafsiran al-Qur'an, menurut pandangan Amina (2001: 33), ada beberapa hal yang harus digaris bawahi, yaitu:

1). Tidak ada penafsiran yang benar-benar objektif

Menurutnya, masing-masing dari ahli tafsir sering melakukan beberapa pilihan subjektif dan terkadang hal itu tidak mencerminkan maksud dari nash-nya. Sebuah produk tafsir selalu dipengaruhi olah pengalaman subjektif dan latar belakang masing-masing orang. Contoh sederhana, orang yang fanatik terhadap ilmu fiqih maka ketika menafsirkan al-Qur'an, akan lebih banyak menggunakan pengalaman fiqih-nya.

2). Tidak adanya pemahaman yang tunggal terhadap ayat-ayat alQur'an

Tidak adanya pemahaman yang tunggal terhadap ayat-ayat alQur'an telah terjadi sejak ayat-ayat tersebut diturunkan dari waktu ke waktu (Asghar Ali Engineer, (tarj.) Agus Nuryanto, 2003: 22). Termasuk adalah para sahabat sebagai generasi yang paling dekat dengan Rasul sekalipun sering berbeda pendapat antara satu dengan yang lainnya. Perbedaan ini pun sampai kepada ulama mufassirin pada periode-periode berikutnya. Jadi, tidak mengherankan bila kemudian muncul penafsiran-penafsiran yang berbeda tentang makna yang terkandung dalam al-Qur'an.

2. Kategorisasi penafsiran al-Qur'an

Penafsiran al-Qur'an, menurut Amina (tarj.) Abdullah Ali (2001: 33-

35) ada tiga kategori, yaitu tradisional, reaktif dan holistik:

a) Tradisional

model tafsir ini menggunakan pokok bahasan tertentu, sesuai kemampuan mufasir-nya, seperti kemampuan dalam bidang hukum, nahwu, sharaf, sejarah, tasawuf dan sebagainya. Maka, tafsir seperti ini bersifat atomistik, artinya penafsiran dilakukan atas ayat perayat dan tidak tematik sehingga pembahasannya terkesan parsial dan tidak ada upaya untuk mengenali tema-tema dan membahas hubungan al-Qur'an dengan dirinya sendiri, secara tematis. Dan yang paling ironi, pada model penafsiran tradisional ini menurut Amina Wadud adalah semuanya hanya ditulis oleh kaum laki-laki. ini berarti bahwa subjektifitas, pengalaman laki-laki dapat dimasukkan ke dalam tafsir mereka dan sementara wanita dan pengalaman wanita diabaikan, maka wajar bila kemudian tafsir yang muncul adalah menurut visi, perspektif, kehendak atau kebutuhan khas laki-laki (patrinial).

b) Reaktif

Tafsir model ini merupakan reaksi para pemikir modern terhadap sejumlah hambatan yang dialami perempuan yang dianggap berasal dari al-Qur'an. Tujuan dan metode yang digunakan berasal dari cita-cita dan dasar pemikiran kaum feminis. Namun, terkadang analisis yang dipakai tidak komprehensif dan sering menyebabkan sikap egoisme perempuan yang tidak sesuai dengan sikap al-Qur'an sendiri terhadap perempuan. Maka, sebenarnya kelemahan ini bisa 
ditekan bila mereka berpegang teguh pada konsep pembebasan terhadap sumber utama (al-Qur'an) dari ideologi dan teologi Islam.

c) Holistik

merupakan penafsiran yang melibatkan banyak persoalan, sosial, moral, ekonomi dan politik modern, termasuk persoalan wanita yang muncul pada era modern. Satu unsur khas untuk menafsirkan dan memahami setiap nash adalah nash sebelumnya yang disusun oleh penafsir yang dipengaruhi oleh suasana bahasa dan budaya saat nash dibaca, maka hal tersebut tidak dapat dielakkan dan dihindari. (Fazlur Rahman, (tarj.) Anas Muhyidin, 1996: 1).

Melalui kesadaran tersebut, Amina Wadud memberikan sebuah tawaran metode ketika akan menafsirkan ayat-ayat al-Qur'an terutama ayat-ayat yang bias gender, yang dikemasnya dalam tiga aspek penting, yaitu :

- Dalam konteks apa ayat tersebut diturunkan.

- Bagaimana pengungkapan lalu apa yang dikatakannya dari komposisi tata bahasa teks ayat tersebut.

- Bagaimana keseluruhan ayat, atau pandangan hidupnya.

Untuk keperluan langkah dalam teknis operasional ketika akan menafsirkan, menurut Komaruddin Hidayat (1996: 166), setiap ayat yang harus dianalisis adalah:

1) Dalam konteksnya

2) Dalam konteks pembahasan topik yang sama dengan al-Qur'an

3) Menyangkut bahasa yang sama dan struktur sintaksis yang digunakan dalam seluruh bagian al-Qur'an.

4) Menyangkut sikap benar berpegang teguh pada prinsip-prinsipal-Qur'an.

5) Dalam konteks al-Qur'an sebagai pandangan hidup.

Dengan metode tersebut, Amina ingin menangkap spirit dan ide-ide al-Qur'an secara utuh, holistik dan integratif hingga tidak terjebak pada teks-teks yang bersifat parsial dan legal formal. Hal ini dianggap penting, karena problem penafsiran al-Qur'an sesungguhnya adalah bagaimana memaknai teks al-Qur'an yang terbatas dengan konteks yang tidak terbatas. Karena, konteks selalu mengalami perkembangan, apalagi pada waktu yang bersamaan kita ingin menjadikan al-Qur'an selalu relevan dengan perkembangan dan tuntutan zaman.

3. Metode yang digunakannya dalam Penafsiran al-Qur'an

Model hermeneutika adalah salah satu bentuk metode penafsiran yang dalam pengoprasiannya dimaksudkan untuk memperoleh kesimpulan makna suatu teks atau ayat, Amina Wadud Muhsin (2006: 19) menawarkan hermeneutika kritisnya yang cukup berbeda dengan yang lainnya, meskipun hermenutika ini diklaim "baru", tapi dengan penuh kejujuran, Amina Wadud Muhsin mengakui terinspirasi dan bahkan sengaja mengggunakan metode yang pernah ditawarkan oleh Faazlur Rahman yaitu "Hermeneutika Tauhid" yang mana hermenutika ini tidak pernah terlepas dengan lima aspek, yaitu: 
1. Dengan konteks apa teks itu ditulis, jika kaitannya dengan al- Qur'ān, maka dalam konteks apakah ayat itu diturunkan atau melihat asbabun nuzul itu sendiri, sedangkan jika berupa hadis, maka lihatlah dulu asbabul wurudnya.

2. Komposisi garamatikal teks yaitu bagaimana teks al-Qur'an menuturkan pesan yang dinyatakannya. Besearta sintaksis bahasa yang digunakan dalm tempat lain yang berada dalam al-Qur'an,

3. Menurut konteks pembahsan tentang topik yang sama dalam al-Qur'an

4. Dari sudut prinsip al-Qur'an yang menolaknya

5. Bagaimana keseluruhan teks (ayat), atau pandangan duniannya. Sering kali, perbedaan pendapat berakar pada perbedaan penekanan terthadap salah satu dari kelima aspek ini.

Menurut Amina Wadud tidak ada metode penafsiran al-Qur'an yang benar-benar objektif. Setiap mufassir menetapkan beberapa pilihan subjektif. Uraian tafsīr mereka sebagian mencerminkan pilihan subjektif. Uraian tafsir mereka sebagian mencerminkan pilihan subjektif itu dan tidak selalu mencerminkan maksud dari teks yang mereka tafsīrkan. Namun, sering kali, orang tidak membedakan antara teks al-Qur'an dan tafsirnya.

Melalui bantuan metode hermeneutika kritisnya diharapkan dapat menjadikan kitab suci al-Qur'an lebih bersikap pluralis terbuka dan toleran terhadap keragaman yang ada baik ragam internal maupun eksternal. Dari sini pesan-pesan yangdigali al-Qur'an tidak mengabaikan faktorfaktor parsial tidak historis dan lepas control. Memperhatikan perkembangan tradisi hermeneutika di atas dan menyadari betapa urgensinnya penafsiran al-Qur'an maka melalui tulisan ini perlu di ungkap persoalan-persoalan yang berkaitan dengan hermeneutika sebagai salah satu metode penafsiran kitab suci.

Pengungkapan ini dianggap ekstra penting setelah menyadari bahwa kitab suci yang di turunkan Allah kepada kita berjalan dalam rentang waktu dan wilayah berbeda. Selain itu apa yang telah dilakukan oleh para mufassir baik pada tahapan membaca memahami menafsirkan memaknai dan memproduksi makna tidak terlepas dari suasana psikologis sosial budaya yang mengitari di mana saja dan kapan saja mereka berada (Rohimin,2007: 47), maka, Amina Wadud (2006: 182) mencoba menawarkan hermenutika kritis tauhid untuk menegaskan betapa alQur'an bersatu pada keseluruhannya. Alih-alih hanya menerapkan beberapa makna sekaligus pada satu ayat dengan sesekali merujuk ke ayatayat lain, kita dapat mengembangkan sebuah kerangka yang mencakup pemikiran sistematis tentang penarikan berbagi korelasi dan, dengan secukupnya, menunjukkan pengaruh utuh dari koherensi al-Qur'an. Salah satu dari tujuan hermeneutika kritis tauhidnya adalah menjelaskan dinamika antara hal-hal yang univesal dan partikular dalam al-Qur'an. Yang terpenting, al-Qur'an berusaha menetapkan basis pedoman moral yang universal. 


\section{PENUTUP}

Amina Wadud adalah seorang seorang tokoh feminis perempuan Islam yang memberikan penafsiran yang lebih jelas. Harus diakui bahwa semangat Qur'ani yang ingin disampaikannya cukup mengemuka. Demikin juga metode penafsirannya yang ditawarkan relatif baik untuk diterapkan dalam rangka mengembangkan wacana tafsir yang sensitif gender. Akan tetapi, hal ini bukanlah hal yang baru, karena sudah diawali oleh Fazlur Rahman. Poin penting yang dapat diambil dari pemikiran Amina Wadud adanya upaya untuk membongkar pemikiran lama dan mitos-mitos lama yang disebabkan oleh penafsiran yang bias patriarki.

\section{DAFTAR PUSTAKA}

Departemen Pendidikan dan Kebudayaan, (1989). Kamus Besar Bahasa Indonesia, Jakarta: Balai Pustaka.

Engineer, Asghar Ali, (2003). The Qur'an Women and Modern Society, tarj Agus Nuryanto, "Pembebasan Perempuan", Yogyakarta: LkiS.

Hassan Shadili, Ensiklopedi Indonesia, Jakarta: PT Ichtiar Baru-Van Hoeve, t.th.

Ihsan Ali Fauzi, (1990). Kaum Muslim dan Tafsir Al-Qurân, Survey Bibliografi atas Karya-karya dalam Bahasa Arab, dalam Jurnal 'Ulum Al-Qurân, no 5, Vol II, 1990/1410 H.

Kementerian Agama RI, (2013). Al-Qur'an dan Terjemahnya, Bandung: Semesta al-Qur'an.

Khudori Soleh, (2003). Pemikiran Kontemporer, Yogyakarta: Jendela, 2003.

Komaruddin, Hidayat, (1996). Memahami Bahasa Agama, Sebuah Kajian Hermenutik, Jakarta: Paramadina.

Mazd al-Din Muhammad Ibn Ya'kub al-Fairuzabadi, (1995). Al-Qamus alMuhith, Beirut: Dar al-Fikr.

M Amin Summa, (2001). Studi Ilmu al-Qur'an 2, Jakarta: Pustaka Firdaus

Muhammad Husain al-Dzahabi, (1976). al-Tafsir wa al Mufassirun, Beirut: Dar al-Fikr.

Rahman, Fazlur, (1996). Islam and Modernity: Transformasi of an Intellectual Tradition, tarj Anas Muhyidin, Jakarta: Pustaka, 1996.

Rohimin, (2007). Metodologi Ilmu Tafsīr \& Aplikasi Model Penafsiran, Bengkulu: Pustaka Pelajar.

Wadud, Amina. (2001). Qur'an Menurut Perempuan, tarj Abdullah Ali, Jakarta: Serambi.

. (2006). Qur'an and Women, (terj.), Ali Abdullah, (Jakarta: PT. Serambi Ilmu Semesta. 